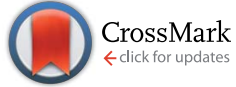

Cite this: RSC Adv., 2017, 7, 15709

Received 23rd November 2016 Accepted 23rd February 2017

DOI: 10.1039/c6ra27202a

rsc.li/rsc-advances

\title{
Convenient iodine-mediated aminoselenation of alkenes using benzotriazoles as nitrogen sources $\uparrow$
}

\author{
Xiaolong Wang, ${ }^{a}$ Hongjie Li, ${ }^{a}$ Min Zhu ${ }^{b}$ and Jie Yan ${ }^{\star a}$
}

A new and convenient procedure mediated by $\mathrm{I}_{2}$ was developed for the preparation of aminoselenides bearing the benzotriazole structure using alkenes, diselenides, and benzotriazoles. In this protocol, molecular $\mathrm{I}_{2}$ first reacts with diselenides to form active electrophilic selenium species, following an electrophilic addition to afford the corresponding aminoselenides. This aminoselenation of alkenes requires mild reaction conditions and is a simple procedure, and it provides the products with high regioselectivity and in good yields, which extends the synthetic application of molecular iodine in organic synthesis.

\section{Introduction}

Organoselenium compounds have been increasing in importance in recent years due to their synthetic applicability, ${ }^{1}$ biological activities, such as antitumor and antibacterial activities, and other properties. ${ }^{2}$ The introduction of organoseleno groups into organic molecules has been widely studied, in which the anti-1,2-addition of an organoseleno group and a nucleophile into an alkene to form vicinal difunctional groups provides a valuable method for synthetic strategies. ${ }^{3}$ The aminoselenation of alkenes is a type of difunctionalization of alkenes, of which, both a selenium atom and amino group can be installed into the carbon-carbon double bond. Despite the vicinal aminoselenides being important in pharmaceutics and in the synthesis of various useful biologically active molecules, there are only a few studies reported on the aminoselenation of alkenes. ${ }^{4}$ Therefore, the development of simple, general, and direct methods for introducing both selenium- and nitrogen-containing groups into alkenes is highly desired.

More recently, using $N$-(phenylseleno)phthalimide (NPSP) as both a nitrogen and selenium source and Lewis acid $\mathrm{TiCl}_{4}$ as a catalyst, Tang and co-workers reported an intermolecular aminoselenation of alkenes with high regioselectivity and diastereoselectivity. ${ }^{5}$ However, the use of metal catalyst, which is required to be removed in the purification and the pre-prepared NPSP, restricts its further application. Moreover, Sun's group demonstrated a new peroxodisulfatemediated aminoselenation of alkenes. ${ }^{6}$ This method is very

${ }^{a}$ College of Chemical Engineering, Zhejiang University of Technology, Hangzhou 310032, P. R. China. E-mail: jieyan87@zjut.edu.cn; Fax: +8657188320238

${ }^{b}$ College of Biological and Environmental Sciences, Zhejiang Shuren University, Hangzhou 310015, P. R. China

$\dagger$ Electronic supplementary information (ESI) available. See DOI: $10.1039 / \mathrm{c} 6 \mathrm{ra} 27202 \mathrm{a}$ interesting because it is general, efficient, and several amino sources, including sulfamides and azoles, are effective in the reaction (Scheme 1). However, compared with various prepared aminoselenides using saccharin as nitrogen source, only one example was reported with benzotriazole as a nucleophile in the reaction.

Over the past few years, iodine-catalysed or iodine-mediated reactions have been increasingly explored because iodine is cheap, readily available, and eco-friendly, and it has metal-like behavior. ${ }^{7}$ We were interested in the oxidation and functionalization of organic compounds using hypervalent iodine reagents because they can promote the oxidative cleavage of the Se-Se bond of diphenyl diselenide, resulting in reactive electrophilic selenium species. ${ }^{8}$ In our recent research, we found that molecular iodine can replace hypervalent iodine reagents to promote some similar reactions. Based on this, to prepare more aminoselenides and research on their unknown chemical and biological properties, we investigated a novel aminoselenation of alkenes using benzotriazoles as amino sources due to the benzotriazole structure being a very useful moiety in the synthesis (Scheme 1). ${ }^{9}$ To the best of our knowledge, this convenient iodine-mediated intermolecular aminoselenation of alkenes has not been reported before.

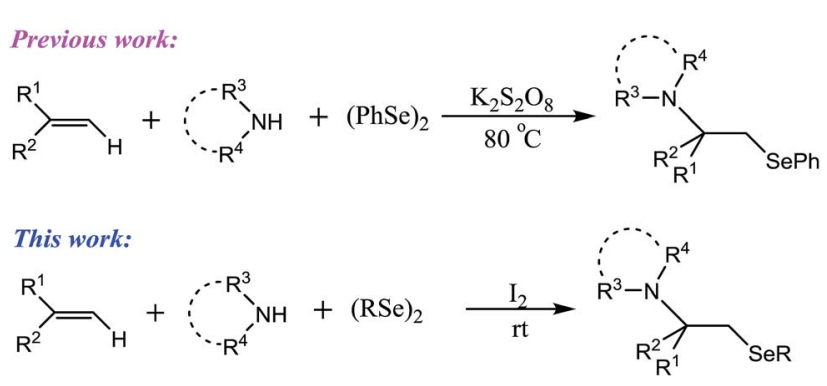

Scheme 1 Methods for alkene aminoselenation. 


\section{Results and discussion}

Initially, we utilized styrene 1a, diphenyl diselenide $\mathbf{2 a}$, and benzotriazole 3a as model substrates to explore the aminoselenation of alkenes in the presence of molecular $\mathrm{I}_{2}$. It was found that on simple stirring of the mixture of 1.2 equiv. of $1 \mathrm{a}$ with 1.0 equiv. of $2 \mathrm{a}, 3 \mathrm{a}$, and $\mathrm{I}_{2}$ in $\mathrm{MeCN}$ for $24 \mathrm{~h}$, the expected aminoselenide, 1-[1-phenyl-2-(phenylseleno)ethyl]-1 $H$-benzotriazole $4 \mathbf{a}$ was obtained in $53 \%$ yield (Table 1, entry 1 ). Then, the aminoselenation of 1.2 equiv. of 1a with 1.0 equiv. of $2 \mathrm{a}$ mediated by $I_{2}$ at room temperature in air was optimized. Several solvents were first evaluated, in which $4 a$ was obtained in the yields ranging from 31 to $53 \%$ (entries 1-6). When more 3a was added in the mixture, the yield increased (entries 7-9). When the yield was not good enough, several mixed solvents were examined to improve the reaction. Fortunately, a mixture of the solvents MeCN and EtOAc was found to be suitable for the reaction, and when the volume ratio reached $1: 1$, the yield increased to $80 \%$ (entries 10-14). In the mixed solvent, the optimal amount of $\mathrm{I}_{2}$ was screened and 1.0 equiv. proved to be the best choice (entries 10,15-17). However, in the absence of $\mathrm{I}_{2}$, 4a was formed only in $10 \%$ yield (entry 18). Other iodinecontaining salts such as $\mathrm{KI}, \mathrm{NaI}$, and $\mathrm{NH}_{4} \mathrm{I}$ were also checked in place of $\mathrm{I}_{2}$, but all were ineffective in the reaction. Under the optimized conditions, the reaction smoothly progressed and was completed in 24 hours (entries 10, 19-20).

Based on the extensive screening process, we obtained the optimal reaction conditions. Next, the aminoselenation of 1.2 equiv. of alkenes 1 with 1.0 equiv. of diselenides 2 and 1.5 equiv. of benzotriazoles 3 in the presence of 1.0 equiv. of $\mathrm{I}_{2}$ in MeCN : EtOAc (1:1) at room temperature for 24 hours was investigated, and as a result, a series of corresponding aminoselenides 4 were obtained. The results are summarized in Table 2.

As shown in Table 2, the $\mathrm{I}_{2}$-mediated aminoselenation was compatible with the studied alkenes $\mathbf{1 a - 1 h}$, affording the corresponding aminoselenides $4 \mathbf{a}-\mathbf{4 h}$ and $\mathbf{4 o - 4 t}$ in good yields. It is obvious that the substituents on benzene ring for these aromatic alkenes, whether they were electron-donating (methyl and $t$-butyl) or electron-withdrawing (bromo and chloro) groups, usually had no significant influence on their reactivity. However, when cyclohexene $\mathbf{1} \mathbf{i}$ and 1 -hexene $1 \mathbf{j}$ were treated as representative aliphatic alkenes, low yields of $41 \%$ and $35 \%$ were obtained for $\mathbf{4} \mathbf{i}$ and $\mathbf{4} \mathbf{j}$, respectively, indicating our protocol is more suitable for aromatic alkenes. Dibenzyl diselenide $\mathbf{2 b}$, similar to $\mathbf{2 a}$, an aliphatic diselenide, was also effective in the reaction, resulting in the corresponding products $\mathbf{4 k - 4 m}$ from aromatic alkenes in good yields and a yield of $40 \%$ for $\mathbf{4 n}$.

Table 1 Optimization of alkene aminoselenation mediated by $I_{2}$

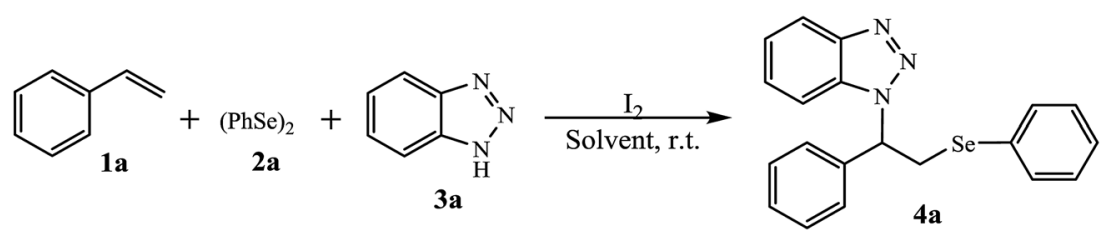

\begin{tabular}{|c|c|c|c|c|c|}
\hline Entry & $\begin{array}{l}\text { Benzotriazole } \\
\text { (equiv.) }\end{array}$ & $\mathrm{I}_{2}$ (equiv.) & Solvent & Time (h) & Yield $^{a}(\%)$ \\
\hline 1 & 1.0 & 1.0 & $\mathrm{CH}_{3} \mathrm{CN}$ & 24 & 53 \\
\hline 2 & 1.0 & 1.0 & $\mathrm{CH}_{2} \mathrm{Cl}_{2}$ & 24 & 52 \\
\hline 3 & 1.0 & 1.0 & EtOAc & 24 & 40 \\
\hline 4 & 1.0 & 1.0 & $\mathrm{CH}_{2} \mathrm{ClCH}_{2} \mathrm{Cl}$ & 24 & 42 \\
\hline 5 & 1.0 & 1.0 & THF & 24 & 35 \\
\hline 6 & 1.0 & 1.0 & DMSO & 24 & 31 \\
\hline 7 & 1.3 & 1.0 & $\mathrm{CH}_{3} \mathrm{CN}$ & 24 & 62 \\
\hline 8 & 1.5 & 1.0 & $\mathrm{CH}_{3} \mathrm{CN}$ & 24 & 69 \\
\hline 9 & 2.0 & 1.0 & $\mathrm{CH}_{3} \mathrm{CN}$ & 24 & 71 \\
\hline 10 & 1.5 & 1.0 & $\mathrm{CH}_{3} \mathrm{CN}: \operatorname{EtOAc}(1: 1)$ & 24 & 80 \\
\hline 11 & 1.5 & 1.0 & $\mathrm{CH}_{3} \mathrm{CN}:$ EtOAc $(2: 1)$ & 24 & 75 \\
\hline 12 & 1.5 & 1.0 & $\mathrm{CH}_{3} \mathrm{CN}:$ EtOAc $(3: 1)$ & 24 & 63 \\
\hline 13 & 1.5 & 1.0 & $\mathrm{CH}_{3} \mathrm{CN}:$ EtOAc $(5: 1)$ & 24 & 60 \\
\hline 14 & 1.5 & 1.0 & $\mathrm{CH}_{3} \mathrm{CN}:$ EtOAc $(1: 2)$ & 24 & 49 \\
\hline 15 & 1.5 & 1.4 & $\mathrm{CH}_{3} \mathrm{CN}:$ EtOAc $(1: 1)$ & 24 & 81 \\
\hline 16 & 1.5 & 0.6 & $\mathrm{CH}_{3} \mathrm{CN}:$ EtOAc $(1: 1)$ & 24 & 53 \\
\hline 17 & 1.5 & 0.2 & $\mathrm{CH}_{3} \mathrm{CN}:$ EtOAc $(1: 1)$ & 24 & 31 \\
\hline 18 & 1.5 & - & $\mathrm{CH}_{3} \mathrm{CN}:$ EtOAc $(1: 1)$ & 24 & 10 \\
\hline 19 & 1.5 & 1.0 & $\mathrm{CH}_{3} \mathrm{CN}: \operatorname{EtOAc}(1: 1)$ & 15 & 70 \\
\hline 20 & 1.5 & 1.0 & $\mathrm{CH}_{3} \mathrm{CN}:$ EtOAc $(1: 1)$ & 10 & 51 \\
\hline
\end{tabular}


Table 2 Alkene aminoselenation mediated by $\mathrm{I}_{2}{ }^{a, b}$<smiles>c1ccc(NSCC(c2ccccc2)n2nnc3ccccc32)cc1</smiles><smiles>Cc1ccc(C(CNc2ccccc2)n2nnc3ccccc32)cc1</smiles><smiles>CC(C)(C)c1ccc(C(CNc2ccccc2)n2nnc3ccccc32)cc1</smiles><smiles>Brc1ccc(C(CNc2ccccc2)n2nnc3ccccc32)cc1</smiles><smiles>Clc1ccc(C(CNc2ccccc2)n2nnc3ccccc32)cc1</smiles><smiles>CC(C)(CNc1ccccc1)C(C)(CNc1ccccc1)c1ccccc1</smiles>

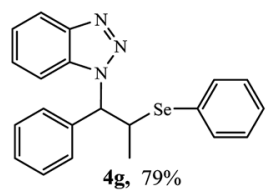<smiles>c1ccc(NC2Cc3ccccc3C2n2nnc3ccccc32)cc1</smiles><smiles>c1ccc(NC2CCCCC2n2nnc3ccccc32)cc1</smiles><smiles>CCCCC(CN=Cc1ccccc1)n1nnc2ccccc21</smiles><smiles>c1ccc(CSCC(c2ccccc2)n2nnc3ccccc32)cc1</smiles>
4 h, $63 \%$<smiles>Clc1ccc(C(CSCc2ccccc2)n2nnc3ccccc32)cc1</smiles><smiles></smiles><smiles>Cc1cc2nnn(C(CNc3ccccc3)c3ccccc3)c2cc1C</smiles><smiles>Cc1ccc(C(CNc2ccccc2)n2nnc3cc(C)ccc32)cc1</smiles><smiles>Cc1cc2nnn(C(CNc3ccccc3)c3ccc(C(C)(C)C)cc3)c2cc1C</smiles><smiles>Cc1ccc2c(c1)nnn2C(CSc1ccccc1)c1ccc(Br)cc1</smiles><smiles>Cc1cc2nnn(C(CNc3ccccc3)c3ccc(Cl)cc3)c2cc1C</smiles><smiles>Cc1cc2nnn(C(C)(CNc3ccccc3)c3ccccc3)c2cc1C</smiles>

${ }^{a}$ Reaction conditions: 1 ( $\left.0.24 \mathrm{mmol}\right), 2$ ( $0.1 \mathrm{mmol}, 0.2$ equiv.), 3 (0.3 mmol), $\mathrm{I}_{2}(0.1 \mathrm{mmol}, 0.2$ equiv.) in $2 \mathrm{~mL}$ MeCN : EtOAc (1 : 1$)$, stirred at r.t. for $24 \mathrm{~h} .{ }^{b}$ Yield of the isolated product.

After investigated the aminoselenation of alkenes using benzotriazole $\mathbf{3 a}$ and 5,6-dimethylbenzotriazole $\mathbf{3 b}$ as amino sources, to prepare more aminoselenides that bear the benzotriazole structure, we then explored the activities of 5methylbenzotriazole $\mathbf{3 c}$ and 5-chlorobenzotriazole $\mathbf{3 d}$ in the reaction. Due to low yields that were usually obtained with aliphatic alkenes, the following aminoselenation was mainly focused on aromatic alkenes (Table 3). Under the optimal reaction conditions, both monosubstituted benzotriazoles typically gave 5-substituted and 6-substituted isomer mixtures 4u-4z2 with yields ranging from 58 to $73 \%$. It is important to isolate the mixed products; however, after several attempts, we failed to achieve the goal. Finally, with ${ }^{1} \mathrm{H}-\mathrm{NMR}$ analysis, the ratio was nearly $1: 1$ for most 5-substituted and 6-substituted isomers.

To explore the mechanism, a stoichiometric radical scavenger, 2,2,6,6-tetramethylpiperidine1-oxyl (TEMPO), was added in the reaction of $\mathbf{1 a}$ with $\mathbf{2 a}, \mathbf{3 a}$, and $\mathrm{I}_{2}$ under the optimized conditions. It was found that the aminoselenation still carried out well, affording the product $4 \mathbf{a}$ in $76 \%$ yield (Scheme 2). This result suggests that the reaction may not undergo a radical pathway. According to the above mentioned results and control experiments, a plausible electrophilic addition mechanism mediated by $I_{2}$ is shown in Scheme 3. Thus, molecular $\mathrm{I}_{2}$ first smoothly reacts with diselenide 2 to form the active intermediate $\mathbf{A}$, followed by a rapid Se-Se bond cleavage. ${ }^{10}$ The in situ generated active electrophilic selenium species then reacts with alkene $\mathbf{1}$ to produce the unstable cyclic seleniranium intermediate $\mathbf{B}$. Finally, intermediate $\mathbf{B}$ is attacked by nucleophile benzotriazole $\mathbf{3}$ to provide the desired product amonoselenide $\mathbf{4}$ as a single isomer via an $\mathrm{S}_{\mathrm{N}} 1$ mechanism. Accompanying the reaction, another active intermediate $\mathrm{ArSeI}^{\mathbf{1 1}}$ can further transfer a second equivalent of electrophilic selenium to alkene 1. As for monosubstituted benzotriazoles $\mathbf{3 c}$ and $\mathbf{3 d}$ resulting in 5-substituted and 6-substituted isomer mixtures, it is mainly that $1 H$-benzotriazole forms a conjugated structure $\mathrm{N}^{-}$ion when it acts as a nucleophile in the reaction. 
Table 3 Aminoselenation of alkenes mediated by $\mathrm{I}_{2}{ }^{a, b}$

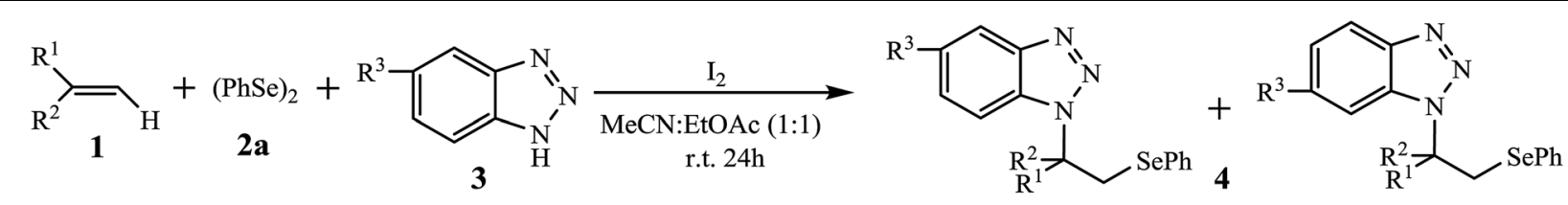<smiles>Cc1ccc2c(c1)nnn2C(CSc1ccccc1)c1ccccc1</smiles><smiles>Cc1ccc(C(C[As]c2ccccc2)n2nnc3cc(C)ccc32)cc1</smiles><smiles>Cc1ccc2c(c1)nnn2C(C[As]c1ccccc1)c1ccc(Br)cc1</smiles><smiles>Cc1ccc2c(c1)nnn2C(C[As]c1ccccc1)c1ccc(Cl)cc1</smiles><smiles>Cc1ccc2c(c1)nnn2C(C)(COc1ccccc1)c1ccccc1</smiles><smiles></smiles><smiles>Cc1ccc(C(CSc2ccccc2)n2nnc3cc(Cl)ccc32)cc1</smiles><smiles>Cc1ccc(C(CSc2ccccc2)n2nnc3ccc(Cl)cc32)cc1</smiles><smiles>Clc1ccc2c(c1)nnn2C(CSc1ccccc1)c1ccc(Br)cc1</smiles>

${ }^{a}$ Reaction conditions: 1 ( $\left.0.24 \mathrm{mmol}\right), \mathbf{2 a}\left(0.1 \mathrm{mmol}, 0.2\right.$ equiv.), 3 (0.3 mmol), $\mathrm{I}_{2}(0.1 \mathrm{mmol}, 0.2$ equiv.) in $2 \mathrm{~mL}$ MeCN : EtOAc (1 : 1$)$, stirred at r.t. for $24 \mathrm{~h} .{ }^{b}$ Yield of the isolated product.

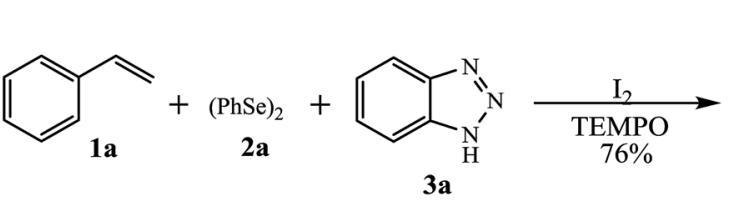<smiles>c1ccc(CSc2ccccc2)cc1</smiles>

Scheme 2

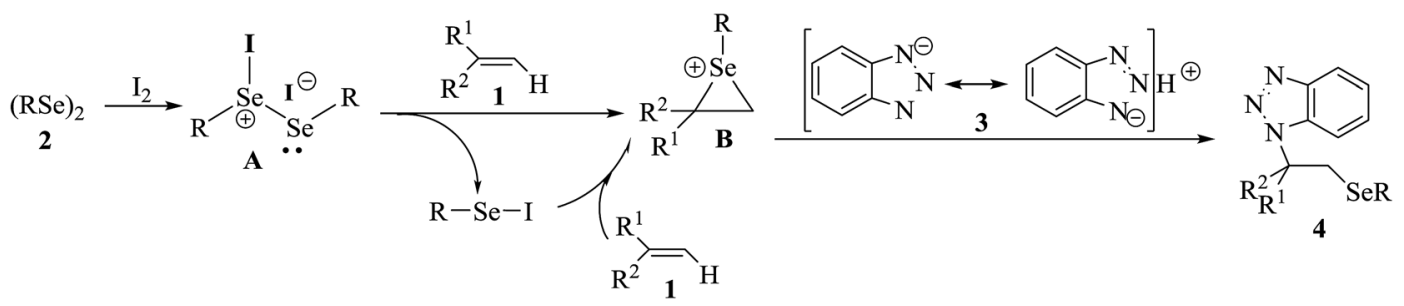

Scheme 3 Proposed mechanism for $\mathrm{I}_{2}$-mediated alkene aminoselenation. 


\section{Conclusions}

In summary, we developed a new and convenient procedure for the preparation of aminoselenides from alkenes, diselenides, and benzotriazoles mediated by $\mathrm{I}_{2}$ at room temperature. This aminoselenation of alkenes has some advantages such as mild reaction conditions and simple procedure, which provides a series of aminoselenides containing benzotriazole structure with high regioselectivity and in good yields. Furthermore, this reaction will extend the application scope of molecular iodine in organic synthesis.

\section{References}

1 (a) T. Wirth, Tetrahedron, 1999, 55, 1; (b) T. Wirth, Angew. Chem., Int. Ed., 2000, 39, 3740; (c) D. M. Freudendahl, S. A. Shahzad and T. Wirth, Eur. J. Org. Chem., 2009, 1649; (d) A. J. Mukherjee, S. S. Zade, H. B. Singh and R. B. Sunoj, Chem. Rev., 2010, 110, 4357; (e) D. N. Jones, D. Mundy and R. D. Whitehouse, J. Chem. Soc., 1970, 86; (f) R. Walter and J. Roy, J. Org. Chem., 1971, 36, 2561; (g) G. Zeni, M. P. Stracke, C. W. Nogueira, A. L. Braga, P. H. Menezes and H. A. Stefani, Org. Lett., 2004, 6, 1135.

2 (a) L. Letavayova, V. Vlckova and J. Brozmanova, Toxicology, 2006, 227, 1; (b) P. Erkekoglu, W. Rachidi, O. G. Yuzugullu, B. Giray, A. Favier, M. Ozturk and F. Hincal, Toxicol. Appl. Pharmacol., 2010, 248, 52; (c) H. E. Ganther, Carcinogenesis, 1999, 20, 1657; (d) A. Hartwig, H. Blessing, T. Schwerdtle and I. Walter, Toxicology, 2003, 193, 161; (e) P. Erkekoglu, B. Giray, W. Rachidi, I. Hininger-Favier, A.-M. Roussel, A. Favier and F. Hincal, Environ. Toxicol., 2014, 29, 98; $(f)$ K. Wallace, K. T. Kelsey, A. Schned, J. S. Morris, A. S. Andrew and M. R. Karagas, Cancer Prev. Res., 2009, 2, 70; $(g)$ K. El-Bayoumy, P. Upadhyaya, V. Date, O. S. Sohn, E. S. Fiala and B. Reddy, Chem. Res. Toxicol., 1991, 4, 560; (h) M. P. Rayman, Proc. Nutr. Soc., 2005, 64, 527; (i) P. Erkekoglu, M.-W. Chao, W. Ye, J. Ge, L. J. Trudel, P. L. Skipper, B. Kocer-Gumusel, B. P. Engelward, G. N. Wogan and S. R. Tannenbaum, Food Chem. Toxicol., 2014, 72, 98.

3 (a) A. A. Vieira, J. B. Azeredo, M. Godoi, C. Santi, E. N. da Silva Júnior and A. L. Braga, J. Org. Chem., 2015, 80, 2120; (b) T. G. Back, The Chemistry of Organic Selenium and Tellurium Compounds, ed. S. Patai, Wiley, Chichester, 1987, vol. 2, pp. 115-134; (c) M. Tiecco, L. Testaferri, M. Tingoli, D. Bartoli and R. Balducci, J. Org. Chem., 1990, 55, 429; (d) M. Tiecco, L. Testaferri, M. Tingoli, D. Chianelli and D. Bartoli, Tetrahedron Lett., 1989, 30, 1417; (e) C. Bosman, A. D'Annibale, S. Resta and C. Trogolo, Tetrahedron Lett., 1994, 35, 6525; (f) N. Taniguchi, J. Org. Chem., 2006, 71, 7874; (g) T. Wirth, Angew. Chem., Int. Ed., 2000, 39, 3740; (h) T. Wirth, Organoselenium Chemistry: Synthesis and Reactions, Wiley-VCH, Weinheim, 2012; (i) E. S. Conner, K. E. Crocker, R. G. Fernando, F. R. Fronczek, G. G. Stanley and J. R. Ragains, Org. Lett., 2013, 15, 5558.

4 (a) A. Toshimitsu, K. Nakano, T. Mukai and K. Tamao, J. Am. Chem. Soc., 1996, 118, 2756; (b) M. Tiecco, L. Testaferri,
C. Santi, C. Tomassini, F. Marini, L. Bagnoli and A. Temperini, Tetrahedron: Asymmetry, 2002, 13, 429; (c) A. Toshimitsu, T. Aoai, S. Uemura and M. Okano, J. Chem. Soc., Chem. Commun., 1980, 1041; (d) A. Toshimitsu, T. Aoai, H. Owada, S. Uemura and M. Okano, J. Org. Chem., 1981, 46, 4727; (e) A. Toshimitsu, G. Hayashi, K. Terao and S. Uemura, J. Chem. Soc., Perkin Trans. 1, 1986, 343; (f) M. Tiecco, L. Testaferri, C. Santi, C. Tomassini, F. Marini, L. Bagnoli and A. Temperini, Angew. Chem., Int. Ed., 2003, 42, 3131.

5 E. Tang, W.-L. Wang, Y.-J. Zhao, M. Zhang and X. Dai, Org. Lett., 2016, 18, 176.

6 K. Sun, X. Wang, Y.-H. Lv, G. Li, H.-Z. Jiao, C.-W. Dai, Y.-Y. Li, C. Zhang and L. Liu, Chem. Commun., 2016, 52, 8471.

7 (a) R. D. Richardson and T. Wirth, Angew. Chem., Int. Ed., 2006, 45, 4402; (b) T. Dohi and Y. Kita, Chem. Commun., 2009, 2073; (c) M. Uyanik, D. Suzuki, T. Yasui and K. Ishihara, Angew. Chem., Int. Ed., 2011, 50, 5331; (d) J. Feng, S. Liang, S.-Y. Chen, J. Zhang, S.-S. Fu and X.-Q. Yu, Adv. Synth. Catal., 2012, 354, 1287; (e) M. Uyanik, H. Okamoto, T. Yasui and K. Ishihara, Science, 2010, 328, 1376; (f) E. Shi, Y. Shao, S. Chen, H. Hu, Z. Liu, J. Zhang and X. Wan, Org. Lett., 2012, 14, 3384; (g) S. Tang, Y. Wu, W. Q. Liao, R. P. Bai, C. Liu and A. W. Lei, Chem. Commun., 2014, 50, 4496; (h) A. Sagar, S. Vidyacharan and D. S. Sharada, RSC Adv., 2014, 4, 37047; (i) K. Yang, M. Ke and Y. G. Lin, Green Chem., 2015, 17, 1395; (j) S.-Ke. Wang, M.-T. Chen, D.-Y. Zhao, X. You and Q.-L. Luo, Adv. Synth. Catal., 2016, 358, 4093; (k) Y.-N. Duan, Z. Zhang and C. Zhang, Org. Lett., 2016, 18, 6176; (l) Y. Siddaraju and K. R. Prabhu, Org. Lett., 2016, 18, 6090; (m) S. Ambethkar, M. Vellimalai, V. Padmini and N. Bhuvanesh, New J. Chem., 2017, 41, 75; (n) D.-D. Xu, W.-W. Sun, Y.-L. Xie, J.-K. Liu, B. Liu, Y.-B. Zhou and B. Wu, J. Org. Chem., 2016, 81, 11081. 8 (a) M. Tingoli, M. Tiecco, D. Chianelli, R. Balducci and A. Temperini, J. Org. Chem., 1991, 56, 6809; (b) M. Tingoli, M. Tiecco, L. Testaferri and R. Balducci, Synlett, 1993, 211; (c) M. Tingoli, M. Tiecco, L. Testaferri and A. Temperini, Chem. Commun., 1994, 1883; (d) M. Tingoli, M. Tiecco, L. Testaferri and A. Temperini, Synth. Commun., 1998, 28, 1769; (e) J. P. Das, U. K. Roy and S. Roy, Organometallics, 2005, 24, 6136; $(f)$ L. Yu, B. Chen and X. Huang, Tetrahedron Lett., 2007, 48, 925; (g) Y. V. Mironov, A. A. Sherman and N. E. Nifantiev, Tetrahedron Lett., 2004, 45, 9107; (h) M. Shi, B.-Y. Wang and J. Li, Eur. J. Org. Chem., 2005, 759.

9 (a) P. P. Dixit, P. S. Nair, V. J. Patil, S. Jain, S. K. Arora and N. Sinha, Bioorg. Med. Chem. Lett., 2005, 15, 3002; (b) N. Mishra, P. Arora, B. Kumar, L. C. Mishra, A. Bhattacharya, S. K. Awasthi and V. K. Bhasin, Eur. J. Med. Chem., 2008, 43, 1530; (c) Z. Rezaei, S. Khabnadideh, K. Pakshir, Z. Hossaini, F. Amiri and E. Assadpour, Eur. J. Med. Chem., 2009, 44, 3064; (d) S. Demirayak, K. Benkli and G. Given, Pharm. Acta Helv., 1998, 72, 285; (e) M. R. Barbachyn and C. W. Ford, Angew. Chem., Int. Ed., 2003, 42, 2010; (f) V. Arora, M. M. Salunkhe, N. Sinha, 
R. K. Sinha and S. Jain, Bioorg. Med. Chem. Lett., 2004, 14, 4647.

10 (a) H.-W. Shi, C. Yu, M. Zhu and J. Yan, J. Organomet. Chem., 2015, 776, 117; (b) C. Muangkaew, P. Katrun, P. Kanchanarugee, M. Pohmakotr, V. Reutrakul,
D. Soorukram, T. Jaipetch and C. Kuhakarn, Tetrahedron, 2013, 69, 8847.

11 (a) Z.-Z. Huang, X. Huang and Y.-Z. Huang, J. Chem. Soc., Perkin Trans. 1, 1995, 95; (b) A. Toshimitsu, S. Uemura and M. Okano, J. Chem. Soc., Chem. Commun., 1982, 87. 